\title{
Perceptions by Smallholder Farmers of Forest Plantations in Malaysia
}

\author{
Jegatheswaran Ratnasingam ${ }^{1, *}$, Florin Ioras ${ }^{2, *}$ (D), Saeid Reza Farrokhpayam ${ }^{3}$, Manohar Mariapan ${ }^{1}$, \\ Hazirah Ab Latib ${ }^{1}$ and Kang Chiang Liew ${ }^{4}$ \\ 1 Faculty of Forestry, Universiti Putra Malaysia, Serdang 43400, Selangor, Malaysia; \\ mano@upm.edu.my (M.M.); hazirahlatib@gmail.com (H.A.L.) \\ 2 Centre for Sustainability, Buckinghamshire New University, Queen Alexandra Road, High Wycombe, \\ Buckinghamshire HP11 2JZ, UK \\ 3 Department of Wood Science \& Technology, University of Zabol, Zabol 98616, Iran; farrokhpayam@uoz.ac.ir \\ 4 Faculty of Tropical Forestry, Universiti Malaysia Sabah, Kota Kinabalu 88400, Sabah, Malaysia; \\ liewkc@ums.edu.my \\ * Correspondence: jegaratnasingam@yahoo.com (J.R.); florin.ioras@bucks.ac.uk (F.I.)
}

check for updates

Citation: Ratnasingam, J.; Ioras, F.; Farrokhpayam, S.R.; Mariapan, M.; Latib, H.A.; Liew, K.C. Perceptions by Smallholder Farmers of Forest Plantations in Malaysia. Forests 2021, 12, 1378. https://doi.org/10.3390/ f12101378

Academic Editor: Alessandro Paletto

Received: 28 September 2021

Accepted: 8 October 2021

Published: 10 October 2021

Publisher's Note: MDPI stays neutral with regard to jurisdictional claims in published maps and institutional affiliations.

Copyright: (c) 2021 by the authors. Licensee MDPI, Basel, Switzerland. This article is an open access article distributed under the terms and conditions of the Creative Commons Attribution (CC BY) license (https:// creativecommons.org/licenses/by/ $4.0 /)$.

\begin{abstract}
Plantation forests are perceived to be the supplementary source of wood material for the large wood products industry in Malaysia, amidst the steadily reducing supply from her natural forests. Despite the government's initiated plantation forests scheme, the participation of smallholder farmers has been limited. Smallholder farmers constitute the largest proportion of private farmers involved in all sectors of agricultural and plantation tree crop cultivation, including commodities such as rubber and palm oil. Therefore, this study examines the lack of interest among smallholder farmers to participate in establishing forest plantations, although they have a strong presence in the palm oil and rubber sectors. A structured questionnaire survey was conducted among 12,895 smallholder farmers currently involved in palm oil, rubber and other tree-crop cultivation. The study found that this group has little knowledge and awareness of the forest plantation scheme available, and there is a prevailing perception that the establishment of forest plantations is not environment-friendly and leads to biodiversity loss. The poor economic return, small land holding, and poorly structured market and supply chain are perceived as the significant constraints faced that limit the interest among the target groups to participate in this sector. Any effort to reverse this trend and garner higher interest from the target group will necessarily require a new policy framework that boosts the economic outlook of forest plantations among smallholder farmers.
\end{abstract}

Keywords: forest plantation; economic viability; smallholder farmers; perception; awareness

\section{Introduction}

Large scale forest plantations in the tropics only started in the 1960s, when deforestation to facilitate agriculture activities, urbanization and other land use purposes had taken place unabetted throughout the region [1]. Although the primary aim of plantation forest establishment was to satisfy the increasing global demand for timber products [2], it was also recognized that plantation forests could become an important carbon sink to mitigate global climate change [3]. Being well managed, forest plantations usually produce better quality wood, with higher yield per hectare on shorter rotations than natural forests [4]. The economic benefits to be derived from forest plantations are often considered more valuable than the threats of biodiversity loss posed by these plantations, due to their monoculture status [5].

According to the Global Forest Assessment [6], the global forest plantation area has reached 294 million ha, with an average annual increment of 1.85\%, since 1990. The higher average annual increment was recorded in North and Central America $(2.51 \%)$, South America (2.38\%) and Asia (2.27\%) [6]. Despite such impressive establishment rates, it is 
estimated that only half of the plantations in Asia, Africa, and Central America are used for industrial wood production, while the remaining serve other purposes, such as fuelwood production and protection from desertification [6].

It is apparent that the southern hemisphere, compared at similar latitudes, continues to gain in forest plantation area, due to the faster growth rate of 30 to $40 \mathrm{~m}^{3}$ per hectare per year, compared to 10 to $15 \mathrm{~m}^{3}$ per hectare per year in the northern hemisphere [3]. In fact, forest plantations have expanded most rapidly in countries with densely populated rural areas that experience rural to urban migration, have large tracts of pasture lands, and have government policies that promote afforestation. According to [6], South America (particularly Chile and Brazil), South Africa, New Zealand and Australia are among the countries with the fastest growing forest plantation areas in the world. It must, however, be recognized that China leads the way in forest plantation establishment in the world, with almost 80 million ha. Against this background, it expected that by 2050, almost $75 \%$ of all wood supply in this region will come from forest plantations, which underlines the importance of industrial forest plantations [7].

\section{Changes in Forest Cover in Malaysia and Its Trade in Wood Products}

Malaysia, positioned close to the equator, has two distinct parts, West Malaysia, which is also known as Peninsular Malaysia, and East Malaysia, on the island of Borneo, comprising the states of Sabah and Sarawak. According to [8], Sarawak accounts for nearly $60 \%$ of the total natural forest production, while Peninsular Malaysia accounts for $28 \%$ and Sabah accounts for $12 \%$. Most timber production in Sarawak is from natural forests, while in Peninsular Malaysia, production is not only from the natural forests, but also from the clearance of rubber plantations. Sabah was forced to depend more on forest plantations as production from the natural forests was fast depleting, and in 2019 a complete ban on log exportation was imposed [8].

Much of Malaysia's natural forest has been degraded. Almost $80 \%$ of the forests in Sabah and Sarawak have been heavily impacted by unsustainable logging. Satellite data indicate that the annual deforestation rate was 1.6\% between 2000 and 2015, and much of the forest loss has been attributed to clearance activities to facilitate agricultural expansion, particularly oil-palm cultivation [9]. On the other hand, official land-use data shows that between 1990 and 2019, Peninsular Malaysia lost about 140,000 hectares of forest more than East Malaysia did, despite being only two-thirds its size [8].

In anticipating further threats to its forest cover, the Malaysian federal government responded by advocating sustainable forestry in the form of the National Forestry Policy. Launched in 1978, the key strategy of the National Forestry Policy was to reclassify a broad swath of natural forests as permanent reserve forests (PRFs). The gazetting of PRFs was important because PRFs are managed to ensure renewable timber stock for perpetuity. Furthermore, the PRF was intended to be the permanent forested area within the country. Within PRFs, about $65 \%$ are classified as production forests to produce timber, while the balance, $35 \%$, is classified as protected forests. Such protected forests are managed by the state, and include non-harvestable forests (areas above certain altitudes, slopes), virgin jungle reserves, recreational forests, catchment forests and reservoirs, national and state parks, and wildlife and bird sanctuaries [10]. Currently Peninsular Malaysia has 1.83 million ha of protected forests, Sabah has 1.88 million ha, and Sarawak has 0.82 million ha [8]. Unfortunately, since land and forest matters are under the jurisdiction of the respective states in the country, the permanency of the PRF is also threatened when the state government decides to de-gazette part of the PRF for other land use, leading to forest cover loss.

Within the production forests in the PRFs, only selected trees above certain sizes are logged. Roads are kept minimal, and logged sites are rested for 30 years for regeneration. Clear-cutting is prohibited within the production forests. States are also allocated an annual quota of logging area set by the National Land Council, a national committee consisting of Chief Ministers of the respective State governments, which is chaired by the Prime Minister. 
This logging quota, called the annual allowable coupe (AAC), allows each state to log up to one-thirtieth $(1 / 30)$ of its production PRFs, so that each site can be rested for 30 years after logging to ensure sufficient regeneration before the next harvest [10].

The principles of sustainable forestry as stipulated in the National Forestry Policy was enacted into legislation by the federal government as the National Forestry Act 1984. The policy and legislation, coupled with the depletion of easy-to-reach lowland Dipterocarp forests, led to the gradual easing of logging pressure in throughout the country. In line with sustainable forest management (SFM) practices, $\log$ production from the natural forests has reduced significantly to a more sustainable level, hence leading to a fall in supply to the large timber products industry in the country. Consequently, timber supplies from other sources are gaining importance in the country.

In essence, there are three main sources of timber in Malaysia:

1. Natural (or semi-natural) forests. Natural forests are under state ownership, except for some alienated (privatized) land, where forest clearance is permitted for private use. Forests under state ownership are broadly classified as either permanent reserved forests (PRF) or state land forests. PRF areas can include commercial forests, protected forests, and communal forests. The total area gazetted as PRF in Malaysia is approximately 13.24 million ha, which is divided between Sarawak with approximately 4.9 million ha, Peninsular Malaysia with 4.8 million ha, and Sabah with 3.54 million ha [8].

2. Forest plantations. Forest plantations are often established in the PRF and managed under private concessions. Peninsular Malaysia has 135,000 ha of forest plantations and Sabah approximately 350,000 ha, while Sarawak has so far planted 446,000 ha within 2,368,000 ha of LPF (license for planted forests) concession areas [8].

3. Agricultural areas. Agricultural areas provide a significant source of timber to the timber processing industries, especially rubber tree plantations (for latex) and to salvage logging for site preparation before planting oil palm or rubber trees. Rubber tree plantations are dominated by smallholder farmers associated with government agencies (the Federal Land Development Authority (FELDA), the Rubber Industry Smallholders Development Authority (RISDA), and the Rubber Industry Development Board of Sabah (LIGS)) that support planting, latex processing, and replanting. Malaysia has an estimated 1.38 million ha of rubber tree plantations, of which nearly $60 \%$ are going untapped due to currently low prices of latex [11].

According to [12], Malaysia produced about 19.1 million $\mathrm{m}^{3}$ of industrial round logs from its natural forests in 2019. Approximately 10\% was exported in the form of round logs, especially from Sarawak, while the balance was consumed domestically for sawn timber, veneer, and plywood production. Eventually, some of these high-quality primary produces were exported as the global demand for tropical wood products remain strong. On the other hand, another 3.1 million $\mathrm{m}^{3}$ of plantation wood was harvested in 2019, but almost $45 \%$ of this was exported, particularly from Sabah and Sarawak.

With exports of wood products from Malaysia exceeding RM 22 billion over the last few years [13], a sustainable supply of wood resource is important. Peninsular Malaysia contributes a major proportion of the sawn timber exports, while veneer and plywood are exported primarily from Sarawak and Sabah. Other products such moldings, and builders' joinery and carpentry (BJC), including doors and frames, are exported mostly from Peninsular Malaysia. In essence, down-stream wood product manufacturing appears to have gained a stronghold in Peninsular Malaysia, while East Malaysian states continue to focus on primary wood products [13].

The competitiveness of the wood products industry in Malaysia relies heavily on the availability of sufficient raw materials and workforce supply. Therefore, any factors (either internal or external) which may affect this equation will have a lasting impact on the sustainability and competitiveness of the wood industry in the country [14]. 


\section{Forest Plantations in Malaysia}

Forest plantation development in Malaysia has had a chequered background. According to [15] forest plantations in Malaysia started as early as 1920s, but the first large scale commercial forest plantations in Malaysia were established in 1967 to feed a proposed pulp and paper mill in Peninsular Malaysia. The fast-growing Pine and Araucaria species were planted for their preferred long fibers, with funding from the Asian Development Bank [16]. Unfortunately, planting efforts fizzled out after a few years because the envisaged pulp mill project did not take off [17].

However, interest in forest plantations was rekindled in 1979, to serve a two-pronged strategy: (1) to regulate and reduce annual log supply and (2) to establish large-scale forest plantations, with the intention of protecting natural forests and creating a sustainable timber source supplying the industry. Hence, the Compensatory Forest Plantation Program (CFPP) was initiated in the early 1980s in Peninsular Malaysia to establish 188,000 ha planted with species such as Acacia mangium, Falcataria moluccana, and Gmelina arborea. The state governments of Sarawak and Sabah in East Malaysia had similar programs, with the aim of ensuring a continuous supply of timber. Unfortunately, enthusiasm for forest plantations dwindled with time as disease problems started to emerge. Heart rot disease and red root rot (associated with Ganoderma philippii) caused high mortality to mature Acacia mangium plantations [18]. Against this background, the forest plantation program failed to live up to its expectations, resulting in disbanded planting activities, as well as severe economic losses.

As the supply of logs from the natural forests in Malaysia reduced from 49 million $\mathrm{m}^{3}$ of harvest in 1990 to 18 million $\mathrm{m}^{3}$ in 2019 [19], the imminent shortage in wood supply became increasingly apparent. To offset the shortage of wood supply, the Ministry of Plantation Industries and Commodities allocated USD 250 million to develop 375,000 ha of forest plantations (25,000 ha per year) in Peninsular Malaysia by the year 2020. The recommended species for planting were rubberwood (Timber Latex Clone or TLC), Acacia spp. (A. mangium and A. auriculiformis), Teak (Tectona grandis), Sentang (Azadirachta excelsa), Khaya spp. (K. ivorensis and K. senegalensis), Kelampayan/Laran (Neolamarckia cadamba), Falcataria moluccana, and Binuang (Octomeles sumatrana). Once successfully implemented, every 25,000 ha of forest plantation established is expected to produce 5 million $\mathrm{m}^{3}$ of timber $\left(200 \mathrm{~m}^{3}\right.$ per ha) [19].

By the end of 2019, a total of 149,000 ha of forest plantations were established in Peninsular Malaysia [19]. On the other hand, Sabah, in East Malaysia, had established 351,000 ha of plantations, consisting largely of Acacia mangium, Falcataria moluccana, Eucalyptus grandis, E. deglupta, E. pellita and N. cadamba, although the targeted planting area was 500,000 ha. Sarawak, also pursued this initiative aggressively (Table 1), and a total of 633,500 ha was planted with similar tree species [19].

Table 1. Forest Plantation Area in Malaysia.

\begin{tabular}{cccc}
\hline \multirow{2}{*}{ Species Planted } & \multicolumn{3}{c}{ Total Planted Area (ha) } \\
\cline { 2 - 4 } & Peninsular Malaysia & Sarawak & Sabah \\
\hline Rubber (Hevea sp.) & 120,000 & 193,000 & 208,000 \\
Oil Palm (Elaeis guineensis) & $2,750,130$ & $1,583,000$ & 154,010 \\
Acacia mangium & 4500 & 283,000 & 40,010 \\
Acacia hybrid & 2000 & 14,000 & 4500 \\
Falcataria moluccana & n. a & 64,500 & 32,200 \\
Neolamarckia cadamba & n. a & 52,000 & 9800 \\
Eucalyptus pellita & 5700 & 8000 & 19,000 \\
Eucalyptus grandis & n. a & 12,000 & 18,000 \\
Eucalyptus deglupta & n. a & 3000 & 4500 \\
Others & 17,000 & 4000 & 15,000
\end{tabular}


Despite the provision of fiscal incentives, such as soft loans payable after 15 years and an investment tax allowance by the government, private sector participation in establishing forest plantations has been limited, especially among smallholder farmers and small private landowners. The majority of the participants are large enterprises, are forest concession holders in Sabah and Sarawak who are obliged to establish forest plantations after harvesting the concessions. Contrastingly, the companies that partake in establishing forest plantations in Peninsular Malaysia have limited experience in forest plantation management. This fact poses a risk, as the success of such companies in previous forest plantation establishments has not been very encouraging [15]. This may also explain why plantation forest establishment in Sabah and Sarawak appears to be more aggressive compared to that in Peninsular Malaysia. According to [19], only 19\% of the total established forest plantations of 1.1 million ha are under smallholder farmer ownership. This is contrary to the scenario in Vietnam, where almost $78 \%$ of all forest plantations are under community and private farmer ownership, which in turn provides the required wood supply and stability to the wood products industry in the country [15].

The opportunity for large scale plantation establishment in Peninsular Malaysia is limited, and the main reason is the lack of large-sized land area. With the except of the large plantation companies which are either involved in palm oil or rubber cultivations, most land available for tree crops is owned by smallholders and private enterprises. In fact, rubber and palm oil cultivation in the country has been dominated by smallholders for a long time [20]. RISDA and FELDA are the two of the largest players in rubber and palm oil cultivation, and they are predominated by smallholders. Large scale plantations of rubber and palm oil account for only $6 \%$ and $14 \%$ of the total land areas cultivated by with these crops in the country [20]. One of the challenges faced by existing smallholder farmers, especially in rubber cultivation, is the low average income due to the low price of natural rubber in the global market. Therefore, the government provides a substantial subsidy to each smallholder farmer to ensure an equitable income and to reduce poverty [20]. These smallholder farmers are usually looking out for opportunities to switch to other tree crops which may provide a better income stream.

On this ground, forest plantations establishment by smallholder farmers appears to be most promising due to their ample land ownership. However, it must be emphasized that most of these smallholder farmers have experience in rubber and palm oil cultivation. Their success can be attributed to the many assistances and nurturing activities undertaken by relevant agencies such as RISDA, FELCRA, the Malaysian Rubber Board (MRB), and the Malaysian Palm Oil Board (MPOB). The question of whether these smallholder farmers will be prepared to switch to forest plantation establishment is the main research question of this study. Smallholder farmers are generally well experienced in tree-crop management, and their success with rubber and oil palm provides ample testimony to this fact. However, the issues related to economic returns and environmental concerns will have to be examined for forest plantations, in comparison to rubber and palm oil cultivation. Another point is that supply chain management in forest plantations has been shown to have a large impact on the success of such ventures. In fact, this has been the hallmark of the success of the small-scaled forest plantations in Vietnam, which has fueled to growth of the hugely successful wood products industry in Vietnam [15]. In a recent article, it was shown that the economic returns, expressed as internal rate of return (IRR) on forest plantations based on a survey of 22 countries, including Brazil, Argentina, United States of America, South Africa, New Zealand, Chile, France, and Poland, was found to range from 3\% to 30\%, without considering the inflation rate. Nevertheless, the economic gains from such ventures were also reported to have declined from 2005 to 2017, suggesting that new approaches are required to ensure the economic viability of forest plantations to suit local conditions [21]. It was also reported that South America appears to be the region with the best economic return and the most sizeable land for forest plantation establishment, compared to all other regions in the world. 
The fact that large forest plantations give higher yield and profits means such forest plantations may not pay too much attention to the workers' welfare and environmental concerns [15]. This is of particular concern, as forest plantations around the world are forging towards green forestry practices while ensuring decent jobs, in line with the Sustainable Development Goals (SDGs). Ironically, smallholder farmers constitute the largest stakeholders in terms of land ownership in the country, and could be potentially exploited for forest plantation establishment. In this context, the question of the limited participation by smallholder farmers in forest plantations warrants further investigation, considering the fact that smallholders predominate the cultivation of tree crops in Malaysia, especially rubber and palm oil.

Therefore, evaluating the limited presence of small-scaled forest plantations in the country is an important research question. In line with the research question, the hypothesis of this study is that smallholder farmers, who make up the largest proportion of private farmers in the country, will venture into forest plantation establishment under viable economic terms and if such ventures prove to be more economical than their existing crops. To this end, the objective of the paper is to assess the perception of the smallholder farmers of establishing forest plantations in the country. Furthermore, the study also aims to determine the level of knowledge and awareness of forest plantations among respondents, and to identify perceived constraints to private forest plantation establishment. The findings of this study will provide insights into remedial measures that could be taken to encourage greater participation of smallholder farmers in the forest plantation sector.

\section{Methodology}

\subsection{Target Respondents}

From a land-use perspective, smallholder farmers account for almost $82 \%$ of all land available for rubber, palm oil, and other perennial tree crop cultivation in the country. According to the Department of Statistics of Malaysia (DOSM), smallholders farmers are the most important stakeholders in the cultivation of rubber, palm oil, and other tree crops in the country, and in order to ensure the economic sustainability of smallholder farmers, the government had formed agencies such as the Federal Land Development Authority (FELDA), the Rubber Industry Smallholders Development Authority (RISDA), and the Federal Land Consolidation and Rehabilitation Authority (FELCRA) which provide assistance to these smallholder farmers [20]. Against this background, the target group in this study is the smallholder farmers who have had a long presence in the field.

To ensure a fair representation of the existing smallholder farmers in the country, and to assess their current involvement in forest plantation, it was important to carry out a questionnaire-based survey with the assistance of the relevant agencies and bodies related to these stakeholders. In Malaysia, smallholder farmers involved in rubber, palm oil and other perennial tree crops are registered with several agencies under the purview of the Ministry of Plantation Industries and Commodities (MPIC).

As of 2019, a total of 587,000 smallholder farmers were involved in rubber $(42 \%)$, palm oil $(52 \%)$ and other perennial tree crop (6\%) cultivation in Malaysia [19]. From this total, $94 \%$ were involved in both rubber and palm oil cultivation, while only $6 \%$ were solely involved in other perennial tree crop cultivation.

To ensure a sufficient sample size of smallholder farmers in this study, the assistance and support of relevant agencies such as FELDA, RISDA, local council offices and local community representatives was obtained. After a series of discussions with the various stakeholders, a total of 28,400 potential smallholder farmers throughout Peninsular Malaysia, Sabah and Sarawak were identified. They were selected based on having a land size of at least 2 ha and have been active farmers for at least 7 years. They were then contacted individually by the respective agencies to seek their consent to participate in this survey. Since this survey coincided with the annual survey conducted by the Ministry of Plantation Industries and Commodities to assess the performance of smallholder farmers in the country, the Ministry agreed that only the questions related to this study were allowed to be made 
public. This was because many socio-economic and other data which will be used for future strategic planning and policymaking for the rubber and palm oil sector were collected in the complete survey questionnaire, which should remain the property of the Ministry of Plantation Industries and Commodities. In this context, to comply with the requirement of the Ministry of Plantation Industries and Commodities, only the parts of the questionnaire used in this study will be revealed in this article, as shown in Appendix A.

A total of 12,895 respondents, or $45.4 \%$ of the targeted respondents, agreed to participate in this study. From this number of respondents, $41 \%$ were involved in rubber cultivation, while another $51 \%$ were involved in palm oil cultivation. Only $8 \%$ of the respondents had been involved in the cultivation of other tree crops, especially fast-growing plantation forest trees. Against this backdrop, it is apparent that a fair representation of the smallholder farmer community has been obtained for this study.

\subsection{Survey Instrument}

The survey instrument used in this study was a structured questionnaire, which was prepared in two languages, i.e., English and Malay. The questionnaire was designed after taking into consideration several previous studies [22-25] and after discussion with stakeholders and experts from the Forest Department of Peninsular Malaysia, RISDA, FELDA, and FELCRA. Prior to the implementation of the survey, the questionnaire was pretested among 15 smallholder farmers of FELDA and RISDA, and based on their feedback and comments, it was improved accordingly. A Cronbach-alpha score of 0.69 was obtained after the testing the reliability of the questionnaire.

The final questionnaire approved by the Ministry of Plantation Industries and Commodities, was 12 pages in length. For the purpose of this study, only four parts of the structured questionnaire were used (Appendix A), while the remaining six parts collected information pertaining to the socio-economic characteristics of the respondents, which will be used by the Ministry of Plantation Industries for their strategic planning activities.

For this study, Part I of the questionnaire collected data on the demographic profile of the respondents, while Part II focused on their level of awareness and knowledge related to forest plantations. The questions were designed to provide a yes/no answer. Part III focused on assessing their overall perception of forest plantations establishments, and the questions required an agree/disagree response. Part IV required the respondents to rank (as major, minor, or not a constraint) the constraints faced by the respondents.

\subsection{Survey Implementation}

The survey was implemented over a period of 8 months, with the assistance of the staff at the regional offices of FELDA and RISDA, due to the large number of respondents. The questionnaire was mailed to the target respondents, and a follow up telephone call was made two weeks later to check on the progress with the questionnaire. After four weeks, another telephone was made reminding them return the filled questionnaire using the self-addressed, stamped envelope provided. Reminders were carried out after two months if the questionnaire had not been returned. At the end of 8 months, the return rate of the questionnaire was $100 \%$, i.e., all respondents had returned the survey questionnaire. Since the extension officers at the regional offices of FELDA, RISDA, and local council were involved in implementing this survey, and the importance in collecting feedback from all respondents, as mandated by the Ministry of Plantation Industries and Commodities, the final response rate was $100 \%$. Although this record is difficult to achieve under normal circumstances, it was made possible due to the importance of the survey and the painstaking coordination of the regional offices.

\subsection{Statistical Analysis of Data}

Due to the large number of respondents, the data from the questionnaires were compiled and tabulated using Microsoft Excel software (Microsoft, version 2010, Las Vegas, NV, USA) to facilitate analysis. The analysis of data was carried out using the Statistical 
Package for the Social Sciences (SPSS; IBM, version 25, New York, NY, USA), and the regional offices that implemented the survey also helped in tabulating the responses obtained from the survey. Frequency distributions and percentages of the responses were calculated for the tabulated data sets. Since the data collected from the survey questionnaire for this study were nominal, the relationship between the constraints that affected the respondents' decision to participate in forest plantation were tested using the Chi-square $\left(\chi^{2}\right)$ and Pearson product moment correlation (PPMC) methods. These tests were suitable for non-parametric data sets, which did not involve and scaled measurements, which inevitably necessitated the use of such tests. These tests provided useful insights in identifying the primary constraints that shaped the decision of smallholder farmers to establish forest plantations.

\section{Result}

The results from this study are presented with an overview of the demographic characteristics of the respondents, followed by the degree of awareness and knowledge related to forest plantations among the respondents. The study was then focused on evaluating the overall perception of the respondents about forest plantations, and finally it examined the main constraints that affected the decision of respondents from participating widely in establishing forest plantations.

The demographic characteristics of the respondents who had participated in this survey is shown in Table 2. The location, age distribution, average land holding, tree crop planted (rubber, palm oil, other tree crop), gender, experience in the field, education level, marital status, and household size were the important demographic characteristics of the respondents captured from the survey.

Table 2. Demographic Characteristics of Respondents.

\begin{tabular}{cc}
\hline Characteristics & Response \\
\hline Age group: 35-65 years & $89 \%$ \\
less than 35 years old & $11 \%$ \\
Average land holding & $2.7 \mathrm{ha}$ \\
Gender (Male) & $100 \%$ \\
Experience in sector: $>$ 10 years & $94 \%$ \\
$5-9$ years & $6 \%$ \\
Education level: secondary & $92 \%$ \\
tertiary (at least Diploma) & $8 \%$ \\
Marital status: married & $98 \%$ \\
bachelor/single & $2 \%$ \\
\hline
\end{tabular}

Table 3 shows that majority ( $68 \%$ ) of the respondents have not heard about forest plantations, while $32 \%$ acknowledged they are aware of forest plantations. In this context, it is apparent that the low level of awareness and knowledge of forest plantations among smallholder farmers can be attributed to the insufficient extension programs to disseminate information about such ventures. Further, the limited land availability for plantation forest establishment, together with the prevailing large tracts of rubber and palm oil plantations in Peninsular Malaysia, may also serve as a strong discouragement for new entrants into this field. According to [15], the notion that forest establishment is the business of the government is still prevalent among the society at large, which also stifles smallholder farmer involvement in such ventures. In fact, smallholders indicated that forests and forest plantations should be the business of the state, as it may to too costly to participate. It is therefore no surprise that the proportion of respondents who are currently practicing agroforestry is low $(6 \%)$, and the prevailing lack of interest in forest plantations clearly indicates that extension services to promote forest plantations involving provision of planting stocks, technical information, and plantation management know-how, is important, and must be actively carried out if this trend is to be reversed. Interestingly, a majority of the respondents (73\%) believed that certification is good and should be 
complied with, as was their experience with the Malaysian Sustainable Palm Oil (MSPO) certification scheme. Unfortunately, none of the respondents could identify any related certification schemes applicable to forest plantations.

Table 3. Level of Awareness and Knowledge of Forest Plantations.

\begin{tabular}{|c|c|c|c|}
\hline S/No. & Item & Yes $(\%)$ & No $(\%)$ \\
\hline 1 & Have you heard about forest plantations? & 32 & 68 \\
\hline 2 & Are you involved in agroforestry? & 6 & 94 \\
\hline 3 & Would you switch your current tree crops with forest plantation tree species? & 35 & 65 \\
\hline 4 & Do you think forest plantations offer more benefits than natural forests? & 23 & 77 \\
\hline 5 & $\begin{array}{c}\text { Do you have difficulty in sourcing good quality planting stock or seedlings for establishing forest } \\
\text { plantations? }\end{array}$ & 74 & 26 \\
\hline 6 & Do you have access for Forest Department expertise or assistance to establish forest plantations? & 32 & 68 \\
\hline 7 & Do you agree than forest plantations are more environment-friendly than natural forests? & 21 & 79 \\
\hline 8 & Do you have knowledge on management and silvicultural operations for forest plantations? & 39 & 61 \\
\hline 9 & Are you aware that forest plantation has a long gestation period? & 89 & 11 \\
\hline 10 & Are you aware of the forest plantation schemes and policies by the government? & 28 & 72 \\
\hline 11 & Are you aware of the main tree species being promoted for forest plantations? & 9 & 91 \\
\hline 12 & Do you agree that certification is desirable in tree crop cultivation? & 73 & 27 \\
\hline 13 & Do you know of any certification scheme applicable to forest and forest plantations? & 0 & 100 \\
\hline 14 & Are indigenous tree species better for forest plantation establishment? & 73 & 27 \\
\hline
\end{tabular}

Table 4 reveals the respondents' perception of forest plantation establishment in the country. It is apparent that most respondents agree with the narrative that forest plantation establishment is rather difficult and cannot be achieved in poor quality soils, as often advocated [15]. Furthermore, they also perceive that forest plantation as a business venture takes too long a time, and its profits are uncertain. From an environmental perspective, the respondents also agree that although forest plantation establishment can support climate change mitigating efforts, it is not a high carbon sink, and therefore, may not be an efficient climate change mitigating agent. This point is attributed to the fact that forest plantations are monocultures. They also believe that forest plantations contribute to biodiversity loss, as forest plantations are often monocultures, and hence, have been shown to be a less efficient carbon storage sink compared to the natural forests [6]. In fact, the study found that most respondents did not agree that forest plantations give good return on investment, a concept which they appear to be very familiar with as the term is widely used during their discussions on rubber and palm oil cultivation with the relevant agencies [11]. The concept of return on investment (ROI) is the ratio of money gained or lost on an investment relative to the cost of the investment appears to be well appreciated among the respondents. The ROI concept allows the respondents to analyze and compare investments to identify the best alternative for their situation. The smallholder farmers are aware of the different costs associated with owning and operating a farm. Simply staying on top of input costs, yields, and market prices is the foundational component for success. For many smallholder farmers, closely weighing the options regarding seeds, chemicals, fertilizer, and equipment is necessary when determining the return on investment based on their experience with rubber and palm oil cultivation [20].

Further, most of these smallholder farmers must service the loans obtained from the Agricultural Bank of Malaysia, which supports rubber and palm oil cultivation activities, and inevitably they are exposed to the necessary economic return concepts. Although the respondents agree that managing forest plantations is difficult, they also hold the perception that the existing policies do not encourage forest plantation establishment, and hence, limit the success of smallholder farmers in this sector. 
Table 4. Respondents' Perception Towards Private Forest Plantation Establishment.

\begin{tabular}{|c|c|c|c|}
\hline S/No. & Respondents' Perception & Agree (\%) & Disagree $(\%)$ \\
\hline 1 & Management of forest plantations is difficult. & 73 & 27 \\
\hline 2 & Forest plantation is a high carbon sink. & 23 & 77 \\
\hline 3 & Forest plantation practices in the country leads to biodiversity loss. & 86 & 14 \\
\hline 4 & Forest plantation is an efficient climate change mitigating agent. & 48 & 52 \\
\hline 5 & The long-term investment in forest plantation is viable. & 24 & 76 \\
\hline 6 & Private forest plantation can be easily established in the country. & 26 & 74 \\
\hline 7 & $\begin{array}{l}\text { Forest plantation is an } \\
\text { important supplier of wood. }\end{array}$ & 43 & 57 \\
\hline 8 & Forest plantation can be established under poor soil or degraded land. & 38 & 62 \\
\hline 9 & Return on investment (ROI) in forest plantation is high. & 14 & 86 \\
\hline 10 & Forest plantation is a source of wood exports, for foreign exchange earnings. & 9 & 91 \\
\hline 11 & There is favorable policy supporting the establishment of forest plantations. & 37 & 63 \\
\hline 12 & Forest plantation establishment can create successful entrepreneurs. & 14 & 86 \\
\hline
\end{tabular}

Table 5 revealed the five most important constraints faced by smallholder farmers to venture into forest plantation are (1) poor economic return from the sale of wood, (2) insufficient supply of good seeds and seedlings, (3) small land holding, (4) lack of finance, and (5) poor extension services from the relevant agencies. Other constraints that also impacted their decision to participate in forest plantations include unclear government policy, poor market structure and supply chain management, land tenure, and the longterm investment or gestation period.

Table 5. Constraints Faced in Forest Plantation Establishment.

\begin{tabular}{|c|c|c|c|}
\hline Constraints & Major & Minor & Not a Constraint \\
\hline Fire outbreak & $4 \%$ & $13 \%$ & $83 \%$ \\
\hline Poor extension service & $81 \%$ & $12 \%$ & $7 \%$ \\
\hline Land tenure system & $75 \%$ & $17 \%$ & $8 \%$ \\
\hline Small land holding & $84 \%$ & $16 \%$ & $0 \%$ \\
\hline $\begin{array}{c}\text { Insufficient supply of quality seeds or } \\
\text { seedlings }\end{array}$ & $86 \%$ & $11 \%$ & $3 \%$ \\
\hline Risk of pests and diseases & $59 \%$ & $29 \%$ & $12 \%$ \\
\hline Lack of technical know-how & $67 \%$ & $24 \%$ & $9 \%$ \\
\hline Long term investment & $71 \%$ & $29 \%$ & $0 \%$ \\
\hline Lack of finance & $84 \%$ & $14 \%$ & $2 \%$ \\
\hline Government policies & $79 \%$ & $12 \%$ & $9 \%$ \\
\hline Shortage of labor supply & $63 \%$ & $29 \%$ & $8 \%$ \\
\hline Poor transportation during raining season & $61 \%$ & $20 \%$ & $19 \%$ \\
\hline Poor economic returns from the sale of wood & $87 \%$ & $13 \%$ & $0 \%$ \\
\hline Market demand uncertain as supply affected by imports & $58 \%$ & $26 \%$ & $16 \%$ \\
\hline Poor market structure and supply chain management & $77 \%$ & $22 \%$ & $1 \%$ \\
\hline
\end{tabular}

The chi-square analysis revealed that a significant relationship exists between poor economic returns, small land holding, and poor market structure and supply chain management on the overall decision to establish forest plantations (Table 6). It is therefore apparent that economic return is the primary consideration for smallholder farmers to venture in forest plantations [26]. The poor economic return can be attributed to the long gestation period of forest plantations, small land area, poor quality planting stock, and lack of finance, which are common to smallholder farmers in the rubber sector as well [11]. 
Table 6. Chi-square Analysis of Constraints and Impact on Decision Making to Establish Forest Plantations.

\begin{tabular}{ccccc}
\hline Variables & $\mathbf{X}^{2}$-Value & $p$-Value & $\begin{array}{c}\text { Impact on } \\
\text { Decision Making }\end{array}$ & $\begin{array}{c}\text { Pearson Product Moment } \\
\text { Correlation (r Value) }\end{array}$ \\
\hline $\begin{array}{c}\text { Poor economic returns } \\
\text { Insufficient supply of quality seeds }\end{array}$ & 26.038 & 0.002 & $\mathrm{~S}$ & 0.319 \\
Small land holding & 12.615 & 0.326 & $\mathrm{NS}$ & - \\
Lack of finance & 21.005 & 0.037 & $\mathrm{~S}$ & 0.321 \\
Poor extension service & 2.340 & 0.674 & $\mathrm{NS}$ & - \\
Government policies & 0.865 & 0.968 & $\mathrm{NS}$ & - \\
Poor market structure \& supply chain & 15.476 & 0.211 & $\mathrm{NS}$ & - \\
Land tenure system & 18.073 & 0.045 & $\mathrm{~S}$ & - \\
Long gestation period & 1.458 & 0.761 & $\mathrm{NS}$ & - \\
\hline
\end{tabular}

$\mathrm{S}=(p \leq 0.05), \mathrm{S}=$ significant, $\mathrm{NS}=$ not significant.

The result of the Pearson product moment correlation (PPMC) between the constraints is highlighted in Table 6, and the decision to establish forest plantations shows a significant correlation $(r=0.319, p=0.04)$. The PPMC test was conducted on the three significant factors identified after the chi-square test. Therefore, this study conclusively shows that forest plantation establishment by private enterprises, farmers and smallholders must address the constraints related to low economic return, small land holding, and poor market structure, if greater participation is to be realized.

\section{Discussion}

It is apparent from Table 2 that all the respondents surveyed in this study have sufficient experience as farmers or grower of tree crops, although the majority of them are involved in either the cultivation of rubber or palm oil. Accordingly, the demographic characteristics of the respondents were parallel to the reports by RISDA and FELDA on the demographic characteristics of their smallholder farmers who are in their scheme [11]. The findings of this survey also imply that rubber, palm oil and tree crop cultivation is not deemed attractive to the tertiary educated workforce, which explains the dependency on ageing 1st generation smallholder farmers and growers. This is in line with the graduate farmers scheme that the government had initiated to entice young agriculture graduates to take up careers as farmers, although its success has been somewhat limited [11]. Inevitably, the lack of tertiary educated farmers or even young graduates participating in plantation establishment may affect the long-term sustainability of these sectors as they lack a professionally trained, knowledgeable workforce that may be adaptable to technology applications to boost yield and competitiveness [9].

The cultivation of rubber and palm oil in Malaysia is a legacy of the British colonial masters, and most plantation management practices were laid down during the colonial period. Since independence in 1957, research and development (R\&D) activities have intensified and further improvements in the yields of both crops were recorded over the years. Unfortunately, due to intense competition from neighboring countries, especially Thailand for rubber and Indonesia for palm oil, the Malaysian rubber and palm oil industries have been somewhat lagging, unable to keep up pace with the rapid expansion of these crops in these countries $[14,20]$. With the lack of interest among young Malaysians to take up careers in the plantation sector, rubber and palm oil cultivation is highly dependent on foreign contract workers, who are a low-cost workforce. Such a measure is preferred among the large plantation operators, as it allows them to keep input costs low.

Table 3 supports that most respondents are familiar with agroforestry practices in rubber and palm oil plantations, where intercropping activities with bamboo, rattan, and other cash crop cultivation were initiated by the respective agencies involved in assisting smallholder farmers to improve their household earnings and livelihoods. Nevertheless, cultivation of forest tree crops has been limited, and reports on the success of agroforestry schemes is grossly lacking [14]. In this context, it is necessary that forest plantation as a 
potential venture should be promoted aggressively among smallholder farmers, coupled with the provision of sufficient know-how and technical support, if greater uptake of forest plantation is to be realized. In this context, incentivizing the participation in forest plantations must be the norm, as it is being practiced for other crops, such as rubber and palm oil.

It is therefore no surprise that most respondents were not aware of the main tree species being promoted for forest plantations, but they believe indigenous species should be the preferred choice (Table 3). Against this background, this study reveals that the respondents' lack of knowledge and awareness appears to be the biggest stumbling block to entice them to participate in forest plantations. Similarly, reports by [24,25], who found that forest plantation establishments in New Zealand and Ecuador, respectively, by private organizations, smallholders and farmers are often boosted by sound extension activities to promote such ventures through information and knowledge sharing sessions. In fact, the reports elucidated that fact that upon sufficient awareness and knowledge of forest plantations among potential participants, the availability of incentives would serve as a positive encouragement to venture into this field.

As reported by $[27,28]$, smallholder farmers were also aware of the fact that forest plantations are usually not successful if the area of cultivation is relatively small (Table 4). Most of the respondents are also concerned about the potential biodiversity loss due to forest plantations, although planting trees will contribute towards mitigating climate change. In this context, the study shares similar findings to that of the study by [27], which clearly stated that the certification of forest plantations should be supported to alleviate some of the risks associated with biodiversity loss.

Although rubber and palm oil cultivation are considered agricultural activities, it must be recognized that the replanting of rubber often involves the removal of the uneconomical standing trees for timber using forestry-type rules for harvest permission [8]. Therefore, the argument for switching from rubber or palm oil to forest plantations may revolve around the questions of economic returns rather than non-feasibility of the venture [14]. In this context, knowledge of new opportunities arising from forest plantation establishment, the absence of constraints related to harvesting operations, and silvicultural support to facilitate and improve forest plantation management must be made accessible to potential smallholder farmers to entice them to explore the possibility of venturing into forest plantations. As elucidated in Tables 4 and 5, the economic return from forest plantation is of paramount importance to smallholder farmers, especially when it comes to making a decision to shift from their existing tree crop to forest plantation tree species. In fact, this issue is of special concern for rubber smallholder farmers as they have been traditionally dependent of government subsidies and assistance to stay above the poverty line for many years due to the slump in the global natural rubber price.

This study also clearly shows that there are similarities between rubber and palm oil cultivations and forest plantation establishment in terms of operations. Nevertheless, the challenges related to the availability of good planting stock, risk of pests and diseases, permission to switch to other tree crops, and the co-benefits of cultivating rubber or palm oil amidst forest plantations must be addressed, as previous experiences with forest plantations in Malaysia has not been overwhelmingly successful $([10,11,14,15])$. In fact, pests and diseases were the major reason for the failure of the Acacia mangium compensatory forest plantation schemes in Peninsular Malaysia in the late 1980s [18]. In fact, even with the current forest plantations throughout the country, the threats posed by pests and diseases remain serious, as noted in Table 5. These concerns remain valid today, as reflected by the responses obtained from the participants of this study.

On one hand, the economic returns from palm oil cultivation appear to be the primary motivation for the rapid expansion in palm oil cultivation area in the country [11]. On the other hand, the low prices of latex or natural rubber in the world market has not only forced many smallholder farmers to switch from rubber to palm oil, but it has also stifled the rate of replanting uneconomical rubber trees. Inevitably, the natural rubber production per 
hectare in Malaysia is much lower than what is being recorded in Thailand and Indonesia, the leading nations in rubber production in the world ([11,14]).

One of the main challenges faced by smallholder farmers in the rubber industry is the low farmgate or stumpage price offered by the middlemen. As a result, the prices obtained per $100 \mathrm{~m}^{3}$ of saw logs by smallholder farmers are often in the range of USD 750, while the sawmillers would pay up to USD 3000 for a similar volume of rubber saw logs. Due to the unscrupulous activities of the middlemen and contractors who distort the market, the economics of rubber wood processing remain unsustainable [20]. Therefore, government policies to boost forest plantation establishment may not achieve the desired targets unless measures are taken to address the shortcomings in economic returns faced by smallholder farmers [29]. Unlike in Vietnam, where smallholder forest plantations are well supported with an extensive supply chain network involving a well-orchestrated distribution channel, such a network does not exist in Malaysia, hence, making smallholders suffer from low income, as reported by [11].

Against this background, it is apparent from the findings of this study that smallholder farmers who, due to their large number, own a substantial land area on a collective basis, offer an opportunity for forest plantation establishment in Malaysia, will have to be convinced of the potential economic return of such ventures. Based on previous experiences in forest plantations which have not been very encouraging on account of the lack of finances, low supply of good quality planting material and prevailing low prices for the wood material produced, efforts must be undertaken that can reverse this trend either through government intervention or regulatory measures.

The government's role in intervening into the market price for wood raw material from forest plantations is not new, as it has been practiced for the rubber and palm oil industry previously, especially when prices of these commodities fall below the target price in the global market. Likewise, a similar mechanism could be introduced for forest plantation schemes, whereby smallholder farmers are assured a minimum farmgate price for the wood raw material produced upon harvest [14]. On the other hand, subvention from the government in forest plantation schemes cannot be practiced due to land tenure and ownership issues which may turn out to be unethical practices by the government in favor of groups of stakeholders [14]. Under such circumstances, proven indirect assistance schemes such as provision of subsidies for seedling acquisition or fertilization could be extended to forest plantations.

\section{Implications of Study}

The Ministry of Plantation Industries and Commodities Malaysia had projected log supply from forest plantations to reach 16.7 million $\mathrm{m}^{3}$ per annum by 2018. Unfortunately, this has not been the case [9]. The targeted establishment of forest plantations did not keep up the pace, and a significant shortfall in cultivated area has been recoded. A targeted total of 350,000 hectares of forest plantations were intended to be established by 2020, but only 137,000 hectares have been realized up to date. The challenges highlighted previously still predominate the decision-making of many potential smallholder farmers who may contemplate the idea of shifting into forest plantations.

Although forest plantations are generally more efficient, with annual incremental yields up to $20-25 \mathrm{~m}^{3}$ per ha/year, poor species-site matching, improper silvicultural practices, and plantation establishment on poor quality soil continue to adversely weigh on the outcomes [30]. In fact, according to the report by [13], factors such as planting site quality, pests and diseases, sufficient supply of quality planting material, and sufficient plantation land area continue to impinge on the success rate of the forest plantation programs throughout the country. It has been shown that forest plantation establishment in East Malaysia, in the states of Sabah and Sarawak, have been growing rapidly over the last few years, but the pace in Peninsular Malaysia has stagnated [15]. Unfortunately, almost $90 \%$ of the value-added wood processing mills are in Peninsular Malaysia, and the wood shortage problem is more acute there. This mismatch in the location of wood resources and 
processing mills has an inherent problem, as Sarawak is still allowed to export its saw logs, while Sabah exports much of its plantation forest products as wood chips to East Asia [13]. Against this background, the problem of overcoming the shortage in wood supply for the large wood processing industry in Peninsular Malaysia may remain unresolved unless regulatory changes to wood trades are imposed in East Malaysian states.

The leading countries of the world that have been successful with large-scale forest plantation establishments include Brazil, South Africa, New Zealand and China. These countries share some common characteristics in their forest plantations, which include sizeable plantation area, intensive and scientific-based plantation management practices, good site-species matching capability, profitable economic returns, and high stumpage value for wood which has a ready market and product application $([31,32])$.

Forest plantation establishments in Malaysia are often compared against rubber and palm oil plantations, which remain the two most important tree crops cultivated in the country. Table 7 provides a comparison in terms of economic benefits from the cultivation of these tree crops based on official data extracted from reports by FELDA, RISDA and FELCRA, the three leading agencies related to smallholder farmers. Due to the sensitivity of obtaining economic figures on earnings and returns, such data were not directly collected from the respondents during the survey. Nevertheless, based on the published data [5], it is apparent that palm oil and rubber appear to be more promising than planting forest plantation tree crops, at least in terms of the cost-benefit ratio (Table 8). On this account, it is apparent that the economic return from forest plantations must be better than those presently derived from rubber and palm oil cultivation, if existing smallholder farmers are to contemplate changing to forest plantations. On the other hand, to attract new smallholder farmers, the program should be sufficiently incentivized, with clear policy guidelines to ensure its economic viability [5].

Table 7. Comparative Economic Benefits of Forest Plantation.

\begin{tabular}{ccccc}
\hline Tree Crop & $\begin{array}{c}\text { Average } \\
\text { Area (ha) }\end{array}$ & $\begin{array}{c}\text { Average Yield per } \\
\text { ha/year }\end{array}$ & $\begin{array}{c}\text { Average Price per Unit } \\
\text { (RM) }\end{array}$ & Average Income per ha/year (RM) \\
\hline Palm Oil & $3-5$ & 4 tons & 3200 per ton & 12,800 \\
Rubber & $2-3$ & $1800 \mathrm{~kg}$ & 1.60 per kg & 2880 \\
Plantation Forest * & 5 & $\begin{array}{c}300 \mathrm{~m}^{3} \text { (at time of } \\
\text { harvest) }\end{array}$ & 100 per $\mathrm{m}^{3}$ of saw logs & $\begin{array}{c}30,000 \text { (at time of harvest) } \\
840 \text { based on NPV on 25-years rotation * }\end{array}$ \\
\hline
\end{tabular}

Data Source: [9,19]. RM = Ringgit Malaysia. * The value of RM 840 is the equivalent rent per hectare of forest plantation based on the calculated on the net present value (NPV).

Table 8. Cost-benefit Analysis of Forest Plantations versus Rubber and Palm Oil on a 25 Year Rotation.

\begin{tabular}{cccccc}
\hline Tree Crop & $\begin{array}{c}\text { Establishment } \\
\text { Cost (RM/ha) }\end{array}$ & $\begin{array}{c}\text { Maintenance Cost until } \\
\text { First Harvest (RM/ha) }\end{array}$ & $\begin{array}{c}\text { Potential Income } \\
\text { (RM/month) }\end{array}$ & $\begin{array}{c}\text { Net Present Value } \\
\text { (RM) }\end{array}$ & B/C Ratio \\
\hline Palm Oil & 5200 & 1050 & 2250 & 51,000 & 8.9 \\
Rubber & 3200 & 1850 & 1400 & 23,000 & 3.7 \\
Acacia Hybrid & 1980 & 800 & - & 18,400 & 2.9 \\
Eucalyptus sp. & 2010 & 800 & - & 21,000 \\
\hline
\end{tabular}

Data Source: [5]. RM = Ringgit Malaysia.

Table 8 provides a cost-benefit analysis of the various tree crops in the country. At the current rate, it is apparent that the economic returns from forest plantations is not comparable to that of rubber and palm oil cultivation, and unless there is a significant change in the economic returns there is little evidence that smallholder farmers would explore the possibility of venturing into forest plantations seriously [5]. The concept of potential income relates to the possibility of sales of produce per month, granting that all conditions enable the smallholder farmer to achieve the output. Nevertheless, this is affected not only by weather conditions, but also by whether harvest is possible and 
the fluctuating prices of the commodities in the global market. In the case of rubber, the smallholder farmers have a steady monthly income flow from the sales of the natural rubber produced by tapping the rubber trees daily. In this context, potential income as a concept is readily acceptable to smallholder farmers, as they are able to enjoy the immediate return from the work put in, rather than wait for 25 years before the forest plantations are harvested in order to obtain the returns. Although the concept of net present value (NPV) is important to assess investment viability, it may not be much appreciated by the smallholder farmers [20]. The NPV determines the difference between the present value of cash inflows of timber benefits and the present value of cash outflows of silvicultural and management costs over a period. The timber benefits are realized in the future when the forest stand is thinned or harvested, and some silvicultural costs and management costs can be also incurred in the future as the forest stand grows. Therefore, both costs and returns need to be discounted back to the present over T years of the forest stand. A discount rate (also called interest rate to consider the time value of money) is determined to solve for NPV. It must be recognized that for most smallholder farmers, daily bread-and-butter issues are more pertinent than long-term investment viability, and therefore the simpler concept of potential monthly income is much more appreciated.

To make forest plantations more attractive to smallholder farmers, the government should ensure a higher price for the wood raw material at the smallholder farmers' end, by enforcing a minimum fair price per $\mathrm{m}^{3}$ for the wood material at the time of harvest. This is particularly important as the prevailing market structure favors the activities of the middlemen who tend to put the squeeze on the smallholder farmers. In this context, the supply chain of wood materials should also be reevaluated to enable the equitable distribution of profits, which will enable smallholder farmers obtain a fair share price [21]. These options may, however, involve some form of financial assistance, but it will help regulate the market price for wood raw material. Financial assistance, either as incentives, grants or loans, must be made accessible to smallholder farmers if they are to be enticed to venture into forest plantations.

One related issue that arises under the present forest plantation program administered by the Malaysian Timber Industry Board (MTIB) is the ban on the export of sawn timber from plantations in Peninsular Malaysia. The huge demand for Acacia wood from Vietnam, which has a booming Acacia wood product manufacturing industry, suggests that the export trade appears to be more lucrative for forest plantation owners [14]. Similarly, the demand for Eucalyptus wood in the international market offers higher prices than what is currently offered in the domestic market [33]. Therefore, if the forest plantation wood resources cannot be exported, and are meant for domestic consumption, where prices are arguably low, it may serve as a disincentive for many to undertake forest plantation establishment [34]. Until and unless the domestic price of the material is increased to be fair and comparable to export market prices, the economic return from forest plantations may be limited.

In this context, this study clearly reveals that smallholder farmers are reluctant to participate in establishing forest plantations primarily for economic reasons. Against the successes of forest plantations in other countries, it is apparent that a long-term vision and well-supported research and development $(R \& D)$ to make such ventures an economic success is a pre-requisite [35]. In this context, the participation of smallholder farmers in forest plantations should be considered due to their long-standing experience in the cultivation of rubber and palm oil. Further, most of the available land banks in Peninsular Malaysia are under smallholder ownership, which makes them potential participants of forest plantation schemes [36]. In this context, unless the concerns and constraints faced by the smallholder farmers are addressed, forest plantation development in the country may remain in the hands of the few, which may inevitably choose to export their produce rather than sell it in the domestic market, as currently seen in East Malaysia. 


\section{Conclusions}

This study shows that awareness and knowledge of forest plantations among smallholder farmers is low in the country due to poor extension activities to promote such activities. Although forest plantations serve as positive agent to mitigate climate change, a majority of respondents perceive biodiversity loss as an inevitable outcome of such ventures. This study confirms that the participation of smallholder farmers in forest plantations is strongly influenced by economic factors. Small land holdings, poor market structure and the improperly developed supply chain are the other major concerns that hinder the participation of smallholder farmers in forest plantation schemes. It is apparent that unless the economic returns from forest plantations are viable and competitive against other tree crops currently cultivated, especially rubber and palm oil, interest to venture into forest plantations may continue to be limited among smallholder farmers. Such an avoidance of forest plantations by this target group should be reversed, as smallholders offer a large tract of available land bank which, if used to establish forest plantations, may positively contribute towards alleviating the timber supply shortage faced in the country. This is particularly important in the country where the large timber product industry is also faced with an increasing shortage of raw material supply to fulfill its own processing needs. Nevertheless, until and unless equitable economic returns from smallholder farmer-owned forest plantations becomes a reality through government financial schemes, the pace of participation by this target group in forest plantations will continue to remain slow.

Author Contributions: Conceptualization, methodology, writing, J.R., F.I.; data collection and analysis, M.M., S.R.F., H.A.L., K.C.L. All authors have read and agreed to the published version of the manuscript.

Funding: The financial support from Universiti Putra Malaysia through the Putra Grant No. 9469900 was helpful in implementing the survey.

Institutional Review Board Statement: Not applicable.

Informed Consent Statement: Not applicable.

Data Availability Statement: Not applicable.

Acknowledgments: The assistance of D. Saeid Reza Farrokhpayam of University of Zabol, Iran, with the implementation of the survey and the data analysis is much appreciated. The financial assistance from Universiti Putra Malaysia through Putra-Grant No. 9469900 to undertake this study is also acknowledged.

Conflicts of Interest: The authors declare no conflict of interest.

\section{Appendix A. Survey Questionnaire}

The questionnaire for this study involved 4 parts. The respondents were required to provide all responses truthfully, and if any questions arose, the relevant extension officers would be able to help.

\section{Part I: Demographic Characteristics of Respondents}

The respondents were requested to fill in their personal particulars based on the following questions. 


\begin{tabular}{cc}
\hline Characteristics & Response \\
\hline Age Group & $\begin{array}{c}\text { More than } 65 \text { years old } \\
\text { Between } 35-65 \text { years old } \\
\text { Less than } 35 \text { years old }\end{array}$ \\
\hline Average land holding (ha) & Palm oil \\
Types of tree crops currently cultivated & Other tree crops \\
\hline Gender & Male \\
Experience in sector & Female \\
\hline Education level & More than 10 years \\
& Between 5-9 years \\
& Less than 5 years \\
\hline Marital status & Primary \\
& Secondary \\
& Tertiary /College \\
\hline Household size (number of persons) & Single \\
\hline
\end{tabular}

\section{Part II: Level of Awareness and Knowledge of Forest Plantations}

Respondents were required to indicate their response to each of the statements below.

\begin{tabular}{|c|c|c|}
\hline S/No. & Item & Yes/No \\
\hline 1 & Have you heard about forest plantations? & \\
\hline 2 & Are you involved in agroforestry? & \\
\hline 3 & $\begin{array}{l}\text { Would you switch your current tree crops with forest plantation tree } \\
\text { species? }\end{array}$ & \\
\hline 4 & Do you think forest plantations offer more benefits than natural forests? & \\
\hline 5 & $\begin{array}{l}\text { Do you have difficulty in sourcing good quality planting stock or } \\
\text { seedlings for establishing forest plantations? }\end{array}$ & \\
\hline 6 & $\begin{array}{l}\text { Do you have access for Forest Department expertise or assistance to } \\
\text { establish forest plantations? }\end{array}$ & \\
\hline 7 & $\begin{array}{l}\text { Do you agree than forest plantations are more environment-friendly } \\
\text { than natural forests? }\end{array}$ & \\
\hline 8 & $\begin{array}{l}\text { Do you have knowledge on management and silvicultural operations } \\
\text { for forest plantations? }\end{array}$ & \\
\hline 9 & Are you aware that forest plantation has a long gestation period? & \\
\hline 10 & $\begin{array}{l}\text { Are you aware of the forest plantation schemes and policies by the } \\
\text { government? }\end{array}$ & \\
\hline 11 & $\begin{array}{l}\text { Are you aware of the main tree species being promoted for forest } \\
\text { plantations? }\end{array}$ & \\
\hline 12 & Do you agree that certification is desirable in tree crop cultivation? & \\
\hline 13 & $\begin{array}{l}\text { Do you know of any certification scheme applicable to forest and forest } \\
\text { plantations? }\end{array}$ & \\
\hline 14 & Are indigenous tree species better for forest plantation establishment? & \\
\hline
\end{tabular}




\section{Part III: Respondents' Perception towards Forest Plantation Establishment.}

The respondents were required to state their agreement or disagreement with each of the statements below.

\begin{tabular}{|c|c|c|}
\hline S/No. & Respondents' Perception & Agree/Disagree \\
\hline 1 & Management of forest plantations is difficult. & \\
\hline 2 & Forest plantation is a high carbon sink. & \\
\hline 3 & Forest plantation practices in the country leads to biodiversity loss. & \\
\hline 4 & Forest plantation is an efficient climate change mitigating agent. & \\
\hline 5 & The long-term investment in forest plantation is viable. & \\
\hline 6 & Private forest plantation can be easily established in the country. & \\
\hline 7 & $\begin{array}{l}\text { Forest plantation is an } \\
\text { important supplier of wood. }\end{array}$ & \\
\hline 8 & $\begin{array}{l}\text { Forest plantation can be established under poor soil or degraded } \\
\text { land. }\end{array}$ & \\
\hline 9 & Return on investment (ROI) in forest plantation is high. & \\
\hline 10 & $\begin{array}{l}\text { Forest plantation is a source of wood exports, for foreign exchange } \\
\text { earnings. }\end{array}$ & \\
\hline 11 & $\begin{array}{l}\text { There is favorable policy supporting the establishment of forest } \\
\text { plantations. }\end{array}$ & \\
\hline 12 & Forest plantation establishment can create successful entrepreneurs. & \\
\hline
\end{tabular}

\section{Part IV: Constraints faced in Forest Plantation Establishment.}

The respondents were required to indicate if they would consider the following constraint a major constraint, minor constraint, or not a constraint, when establishing forest plantations.

\begin{tabular}{cc}
\hline Constraints & $\begin{array}{c}\text { Major/Minor/Not a } \\
\text { Constraint }\end{array}$ \\
\hline Fire outbreak & \\
\hline Poor extension service & \\
\hline Sand tenure system & seedlings land holding \\
\hline Insufficient supply of quality seeds or \\
\hline Risk of pests and diseases \\
\hline Lack of technical know-how \\
\hline Long term investment \\
\hline Lack of finance \\
\hline Government policies \\
\hline Shortage of labor supply \\
\hline Poor transportation during raining season \\
\hline Market demand uncertain as supply affected by imports \\
\hline market structure and supply chain management \\
\hline
\end{tabular}


The survey was implemented through the relevant agencies, and the assistance of the many extension officers were useful in carrying out the survey. The questionnaires were then collected and compiled at the regional offices of the relevant agencies, that helped tabulate the data for further analysis.

\section{References}

1. Szulecka, J.; Pretzsch, J.; Secco, L. Paradigms in tropical forest plantations: A critical reflection on historical shifts in plantation approaches. Int. For. Rev. 2014, 16, 128-143. [CrossRef]

2. Food and Agricultural Organization of the United Nations. Global Forest Resources Assessment 2015. How Are the World's Forests Changing? 2nd ed.; Food and Agricultural Organization of the United Nations: Rome, Italy, 2016; Available online: http:/ / www.fao.org/3/a-i4793e.pdf (accessed on 29 August 2018).

3. Siry, J.P.; Cubbage, F.; Ahmed, M.R. Sustainable forest management: Global trends and opportunities. For. Policy Econ. 2005, 7, 551-561. [CrossRef]

4. Campinhos, J.E. Sustainable plantations of high-yield shape Eucalyptus trees for production of fiber: The Aracruz case. New For. 1999, 17, 129-143. [CrossRef]

5. Ratnasingam, J. Status and Challenges of Plantation Forestry in Malaysia: A Cost-Benefit Analysis; Report for the Investment Unit of Malayan Banking Group Berhad: Kuala Lumpur, Malaysia, 2019.

6. Food and Agricultural Organization of the United Nations. Global Forest Resources Assessment 2020; Main Report; Food and Agricultural Organization of the United Nations: Rome, Italy, 2020; Available online: https:/ / doi.org/10.4060/ca9825en (accessed on 14 November 2020).

7. Korhonen, J.; Toppinen, A.; Cubbage, F.; Kuuluvainen, J. Factors driving investment in planted forests: A comparison between OECD and non-OECD countries. Int. For. Rev. 2014, 16, 67-77. [CrossRef]

8. FDPM. Physical Progress and Status of Forest Plantation Development-Updates; Ministry of Primary Industries and Commodities: Putrajaya, Malaysia, 2020.

9. Ministry of Plantation Industries and Commodities. Status of Forest Plantations in Malaysia; MPIC: Putrajaya, Malaysia, 2019.

10. Ratnasingam, J.; Ioras, F. Colonial British Forestry in Malaysia and the Years Thereafter; Tropical Resources Network Publication: Kuala Lumpur, Malaysia, 2006.

11. Rubber Industry Smallholders Development Authority. Status of Rubber and Palm Oil Smallholders in Malaysia; Ministry of Rural Development: Putrajaya, Malaysia, 2020.

12. International Tropical Timber Organization. Wood Products Trade Statistics-South East Asia; ITTO: Yokohama, Japan, 2020.

13. Malaysian Timber Industry Board (MTIB). Annual Report of the Malaysian Wood Industry; Malaysian Timber Industry Board: Kuala Lumpur, Malaysia, 2020.

14. Ratnasingam, J. Success and Challenges of Plantation Forestry in Malaysia-Lessons for the Future; Report for the Centre for Resource Industries, PT Wirajaya Group: Singapore, 2020.

15. Ratnasing, J.; Latib, H.A.; Paramjothy, N.; Liat, L.C.; Nadarajah, M.; Ioras, F. Plantation forestry in Malaysia: An evaluation of its successes and failures since the 1970. Not. Bot. Horti. Agrobot. Cluj-Napoca 2020, 48, 1789-1801. [CrossRef]

16. Freezailah, C.Y.; Fielding, J.M. The Development and Results of the Pilot Plantation Project and Prospects for the Future; FO: SF/MAL/12. Working Paper No.18; FAO: Rome, Italy, 1971.

17. Johari, B.; Chin, T.Y. Review of plantation experiences in Peninsular Malaysia. In Proceedings of the Ninth Malaysian Forestry Conference, Kuching, Malaysia, 13-17 October 1986; pp. 213-242.

18. Lee, S.S. Pathology of tropical hardwood plantations in South-East Asia. N. Z. J. For. Sci. 2003, 33, 321-335.

19. Malaysian Timber Industry Board (MTIB). Annual Report of the Malaysian Wood Industry; Malaysian Timber Industry Board: Kuala Lumpur, Malaysia, 2019.

20. Ratnasingam, J.; Mohamed Rasif, M.A.; Latib, J.A.; Muttiah. Small-Scale Forest Plantations in Malaysia-Taking Community and Smallholder Participatory Forestry; Report No. 14A; UPM Press: Selangor, Malaysia, 2018.

21. Cubbage, F.; Kanieski, B.; Rubilar, R.; Bussoni, A.; Olmos, V.M.; Balmelli, G.; Mac Donagh, P.; Lord, R.; Hernández, C.; Zhang, P.; et al. Global timber investments, 2005 to 2017. For. Policy Econ. 2020, 112, 102082. [CrossRef]

22. Adebayo, A.S.; Olusina, O.P.; Ogunwale, O.G.; Adekunle, A.; Adekola, P.J. Perception of Farmers towards Private Forest Plantation Establishment in Osun State. J. Res. For. Wildl. Environ. 2020, 12, 154-161.

23. Palmieri, N.; Suardi, A.; Pari, L. Italian Consumers' Willingness to Pay for Eucalyptus Firewood. Sustainability 2020, 12, 2629. [CrossRef]

24. Dhakal, B.; Bigbsy, H.; Cullen, R. Determinants of Forestry Investment and Extent of Forestry Expansion by Smallholders in New Zealand. Rev. Appl. Econ. 2008, 4, 65-76.

25. Dahik, C.Q.; Crespo, P.; Stimm, B.; Murtinho, F.; Weber, M.; Hildebrandt, P. Contrasting Stakeholders' Perceptions of Pine Plantations in the Páramo Ecosystem of Ecuador. Sustainability 2018, 10, 1707. [CrossRef]

26. Bleyer, M.; Kniivilä, M.; Horne, P.; Sitoe, A.; Falcão, M.P. Socio-economic impacts of private land use investment on rural communities: Industrial forest plantations in Niassa, Mozambique. Land Use Policy 2016, 51, 281-289. [CrossRef]

27. Diaz-Balteiro, L.; De Jalón, S.G. Certifying Forests to Achieve Sustainability in Industrial Plantations: Opinions of Stakeholders in Spain. Forests 2017, 8, 502. [CrossRef] 
28. Cuong, T.; Chinh, T.T.Q.; Zhang, Y.; Xie, Y. Economic Performance of Forest Plantations in Vietnam: Eucalyptus, Acacia mangium, and Manglietia conifera. Forests 2020, 11, 284. [CrossRef]

29. Anderson, N.M.; Williams, K.J.; Ford, R.M. Community perceptions of plantation forestry: The association between place meanings and social representations of a contentious rural land use. J. Environ. Psychol. 2013, 34, 121-136. [CrossRef]

30. Dai, J.; Welham, C.; Cao, L.; Cao, F. Sustainable production in subtropical hybrid poplar plantations. J. Trop. For. Sci. 2016, 28, 190-204.

31. Stephens, S.S.; Wagner, M.R. Forest plantations and biodiversity: A fresh perspective. J. For. 2007, 105, 307-313.

32. Miller, E.; Buys, L. 'Not a local win': Rural Australian perceptions of the sustainable impacts of forest plantations. Rural. Soc. 2014, 23, 161-174. [CrossRef]

33. Hii, S.; Ha, K.; Ngui, M.; Penguang, S.A.; Duju, A.; Teng, X.; Meder, R. Assessment of plantation-grownEucalyptus pellitain Borneo, Malaysia for solid wood utilisation. Aust. For. 2017, 80, 26-33. [CrossRef]

34. Daigneault, A.J.; Sohngen, B.; Sedjo, R. Exchange rates and the competitiveness of the United States timber sector in a global economy. For. Policy Econ. 2008, 10, 108-116. [CrossRef]

35. Tham, L.T.; Darr, D.; Pretzsch, J. Contribution of Small-Scale Acacia Hybrid Timber Production and Commercialization for Livelihood Development in Central Vietnam. Forests 2020, 11, 1335. [CrossRef]

36. Nambiar, E.K.S.; Harwood, C.E.; Mendham, D.S. Paths to sustainable wood supply to the pulp and paper industry in Indonesia after diseases have forced a change of species from acacia to eucalypts. Aust. For. 2018, 81, 148-161. [CrossRef] 